\title{
МЕЖДУНАРОДНО-ПРАВОВОЕ ЗНАЧЕНИЕ ИНФОРМАЦИОННОЙ БЕЗОПАСНОСТИ В СИСТЕМЕ ВЗАИМОДЕЙСТВИЯ ГОСУДАРСТВ-ЧЛЕНОВ ЕВРОПЕЙСКОГО СОЮЗА ПО ОБЕСПЕЧЕНИЮ ЗАКОННОСТИ И ПРОТИВОДЕЙСТВИЯ ПРЕСТУПНОСТИ
}

Аннотация. В работе рассматриваются международно-правовые формы взаимодействия государств-членов Европейского Союза в аспекте обеспечения законности и противодействия преступности на международном уровне. Отмечается, что четко налаженное международное информационное взаимодействие правоохранительных органов европейских государств является необходимой предпосьлкой для организации совместной деятельности по противодействию преступности. Получение своевременной правовой помощии по уголовным делам, включая криминалистическую, оперативно-розыскную и иную информацию, является одним из ключевых моментов успеха в деле борьбы с преступностью. Анализируется международно-правовое значение информационной безопасности в рамках Европейского Союза. При помощии диалектического метода, а также традиционно важной роли сравнительно-правовой методики изучения законодательства, призванного обеспечить борьбу с преступностью, в статье проводится оценочный анализ слабых и сильных сторон международно-правовых форм совместных расследований трансграничных преступлений. В работе также используются структурный, системно-логический и формально-юридические методы. Отмечается, что предложения и рекомендации в сфере сотрудничества правоохранительных органов европейских государств, разрабатываемые применительно к странам ЕС, предметно востребованы на теоретическом и практическом уровне как пример взаимодействия государств (в специильной области) и смогут получить свое дальнейшее развитие в формате Евразийского экономического союза (ЕАЭС), аналога Евросоюза. Выводы статьи могут быть полезны правоприменительным органам при раскрытии и расследовании трансграничных преступлений.

Ключевые слова: Законность, Европейский Союз, информационная безопасность, международно-правовое значение, объединеннье следственные бригады, формы сотрудничества, борьба с преступностью, Европол, защищенная сеть, Евроюст.

Abstract: This article examines the international legal forms of cooperation between the member-states of the European Union in the context of lawfulness on fight against crime on international level. The author notes that the finely tuned information exchange of the law enforcement agencies of the European nations is a necessary component in organizing mutual efforts on crime counteraction. Receiving timely assistance in criminal cases, including criminal, investigative, and other data is one of the key elements in successful fight against crime. The author analyzes the international legal role of information security within the framework of the European Union. The conclusions of this article may be useful to law enforcement agencies in investigation of transboundary crimes.

Keywords: Fight against crime, forms of cooperation, joint investigation team, international legal role, information security, European Union, lawfulness, Europol, secure network, Eurojust.

216 


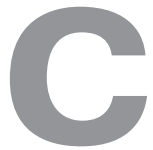
овременный миропорядок позиционирует себя в формате общих (для всех государств) целей и принципов Организации Объединенных Наций. Устав ООН в этом плане выступает в качестве нормоустанавливающего документа современности. Включенность государств-членов мирового сообщества в современный миропорядок обозначена предметной востребованностью всестороннего соблюдения корпуса международных обязательств в соответствии с Уставом ООН. Международная нормативная система, будучи целостной системой права, исключает всякую пробельность в праве и прямо предписывает мирное разрешение международных споров через обращение в Международный суд как главный судебный орган ООН. В этом смысле Международный суд в своем качестве органа по обеспечению права содействует поддержанию целостности универсальной системы международной безопасности. Качественные показатели права и справедливости в формате источниковой базы современного международного права (ст. 38 Статута Международного суда) подтверждают свою действенность.

По своему сущностному содержанию универсальная система международной безопасности в параметрах своего субъектного состава и предмета регулирования в институционно-правовом плане упорядочена в формате верховенства права $[5,6,9,11,19]$. Заявленная приверженность государств-членов мирового сообщества верховенству права (Декларация тысячелетия 2000 г., Итоговый документ Всемирного саммита 2005 г.) показательно конкретно подтверждают готовность государств содействовать укреплению Международного суда как главного су- дебного органа ООН в порядке обеспечения правосудия и верховенства права в международных делах (Декларация тысячелетия 2000 г., раздел VIII; Итоговый документ Всемирного саммита 2005 г., раздел 134). Основополагающим элементом построения международной нормативной системы исключительно и предметно в режиме верховенства права является выполняемость международных обязательств независимо от источника их возникновения на основе принципа добросовестности bona fides $[3,6,7,8,12$, $13,18,20,22]$.

Предметная востребованность выстраивания межгосударственных отношений с учетом добросовестного выполнения всеми странами-участниками межгосударственного процесса взаимодействия своих международных обязательств обозначена в параметрах общей заинтересованности всего мирового сообщества. В п. 2 ст. 2 Устава ООН на этот счет сказано: «Все Члены Организации Объединенных Наций добросовестно выполняют принятые на себя по настоящему Уставу обязательства, чтобы обеспечить им всем в совокупности права и преимущества, вытекающие из принципа принадлежности к составу Членов Организации».

Установка на всеобщность востребованности добросовестного выполнения своих международных обязательств предметно выводит на позиционирование системы международного права как целостной и законченной системы права, при которой добросовестное выполнение международных обязательств выступает неотъемлемым условием построения справедливого миропорядка с равной юридической безопасностью (совокупность субъективных прав и законных ин- 
тересов) всех субъектов международного взаимодействия.

Выход предметной востребованности добросовестного выполнения международных обязательств со стороны всех государств-членов мирового сообщества на установку равной юридической безопасностью применительно ко всем потенциальным участникам процесса международного взаимодействия государств предопределен конкретной исключаемостью в данном случае злоупотребления правом [4, 6, 8, 12, 18, 20].

Концептуально и практически установлено, что добросовестное выполнение международных обязательств (независимо от источника их возникновения) предметно создает условия по недопущению нарушения обязательства по ненанесению ущерба субъективным правам и законным интересам контрагентов международного общения. Государства призваны так осуществлять пользование своими субъективными правами, чтобы тем самым не нарушались субъективные права и законные интересы другого государства. Таким образом, юридическая безопасность государств как институто-образующая основа современного миропорядка обеспечивается в полной мере. По обстоятельствам сказанного, весь спектр предметного регулирования понятия «юридическая безопасность», в том числе, разумеется, и информационная безопасность подпадает под регулятивное воздействие современного международного права. В той мере, в какой юридическая безопасность государства покрывает собой всю совокупность субъективных прав и законных интересов государства вообще, информационная безопасность предметно касается обеспечения субъективных прав и законных интересов государств в сфере информации.

Институт информационной безопасности по факту своей международно-правовой значимости в своем логически юридическом содержании касается и предметно применим в аспекте взаимодействия государств-членов Европейского Союза по пресечению международной преступности.

С самого начала своего существования ЕС в качестве средства повышения эффективности борьбы с трансграничной преступностью предусматривал развитие более тесного сотрудничества правоохранительных органов стран-членов ЕС в сфере внутренних дел и юстиции, которое привело к значительному уменьшению сроков выполнения запросов по оказанию взаимной правовой помощи по уголовным делам, а также к упрощению и улучшению соответствующих юридических процедур. С этой целью Советом ЕС был разработан двусторонний подход к решению указанной проблемы: с одной стороны предполагалось возрастание личной ответственности таких «наднациональных» правоохранительных органов как Европол, Евроюст и Европейского бюро по борьбе с мошенничеством (European Anti-Fraud Office - OLAF) за обеспечение сотрудничества государств ЕС по уголовным делам, а с другой стороны - разработка европейских конвенций по экстрадиции и правовой помощи, принятие которых способствовало установлению прямых контактов, техническому развитию и совершенствованию методов раскрытия и расследования трансграничных преступлений.

Сотрудничество правоохранительных органов Европейского Союза в борьбе с 
преступностью имеет свою специфику, ряд особенностей, а также черты, не характерные для иных региональных и интеграционных объединений. Так, по Лиссабонскому договору [15] для международных региональных правоохранительных организаций ЕС стало характерным то, что правовые основы их деятельности могут закрепляться не только межгосударственными договорами, созданными на основе межгосударственных соглашений (уставов, статутов или иных учредительных документов), но и правовыми актами Европейского Союза [16].

В параметрах юридической науки представляется востребованным выделить следующие формы осуществления сотрудничества в ЕС:

- путем непосредственного взаимодействия правоохранительных органов европейских государств в рамках EC;

- путем взаимодействия государств членов ЕС через специально созданные учреждения Союза, его специализированные органы и структурные подразделения институтов, в компетенцию которых входят вопросы борьбы с преступностью [1].

В концептуально правовом плане представляется предметно обозначить еще две формы осуществления сотрудничества, которые в настоящее время актуальны в сфере противодействия трансграничной организованной преступности. Конкретно это осуществляется следующим образом. Первое, через непосредственное взаимодействие правоохранительных органов государств - членов ЕС и представителей государственных или частных компаний через специально созданные организации и объединения. Второе, через взаимодей- ствие специально созданных учреждений $\mathrm{EC}$, специализированных органов ЕС и структурных подразделений его институтов, в компетенцию которых входят вопросы борьбы с преступностью, и государственных или частных компаний, которые непосредственно не задействованы в процесс обеспечения безопасности и правопорядка.

С момента становления обязательного сотрудничества компетентных органов государств-членов ЕС по уголовным делам в учредительные договоры ЕС были внесены существенные изменения, способствующие повышению эффективности борьбы с организованной трансграничной преступностью. В зарубежной юридической литературе, в документах OОН и иных международных нормативно-правовых актах в настоящее время используется термин «трансграничная организованная преступность» (crossborder organized crime, trans-border organized crime) взамен термина «транснациональная организованная преступность», применявшегося ранее. Это связано с международной системой защиты прав и свобод человека. В ЕС не допускается использовать национальный признак в качестве характеристики преступной группировки. Так, например, говорят об организованной преступной группировке, говорящей на албанском языке (Albanianspeaking OCGs).

С учетом положений международной системы защиты прав человека, полагаем возможным предложить использование термина «трансграничная преступность» взамен термина «транснациональной преступности», при этом под понятием «трансграничная преступность» следует понимать совокупность общеуголовных 
преступлений, имеющих организационный характер международного уровня и подпадающих под юрисдикцию двух и более государств. Указанные преступления не являются предметом криминализации на международном уровне, но их раскрытие и расследование связано с необходимостью совместных действий правоохранительных органов различных государств с возможным участием международных региональных организаций.

Что касается правового регулирования международного сотрудничества в борьбе с преступностью, то имеются некоторые несоответствия правовых норм в международных документах. Например, положениями Палермской конвенции ООН против транснациональной организованной преступности предусмотрено, что одним из признаков организованной преступной группы является наличие не менее трех ее участников. УК Российской Федерации предполагает преступную группу при наличии сговора между двумя и более лицами. В соответствии с критериями Европола организованная трансграничная преступная группа отвечает следующим условиям: 1) взаимодействие двух или более человек; 2) распределение ролей (задач); 3) длительная или неограниченная по времени деятельность; 4) наличие дисциплины или внутреннего контроля; 5) совершение тяжких и особо тяжких преступлений; 6) распространение криминальной деятельности в международном масштабе; 7) применение насилия; 8) использование экономических или коммерческих структур; 9) вовлечение в отмывание денег; 10) влияние на политических деятелей, СМИ, государственные органы, судебные власти или экономи- ческую деятельность (коррупция); 11) целью деятельности является получение прибыли или власти.

Постановочно, для того чтобы лица, занимающиеся противоправной деятельностью, были признаны преступной организованной группой, их объединение должно в обязательном порядке соответствовать условиям, изложенным в п. 1, 3, 5 и 11, а также любым двум из вышеуказанных.

В современных условиях простого роста числа новых участников сотрудничества для борьбы с терроризмом и организованной трансграничной преступностью уже недостаточно. Актуализация криминальных угроз повсеместно в мире требует активизации и углубления взаимодействия полицейских служб, использование новых форм сотрудничества, в первую очередь в рамках Интерпола и Европола. Поэтому в европейском сообществе наметилась устойчивая тенденция к возрастанию роли и значения межгосударственного сотрудничества правоохранительных органов в сфере борьбы с преступностью.

Так, в соответствии со ст. 3 Решения Совета ЕС от 6 апреля 2009 г. основной целью, стоящей перед Европолом, является поддержка и усиление деятельности компетентных органов государств-членов ЕС и их взаимного сотрудничества в борьбе с организованной преступностью, терроризмом и иными тяжкими преступлениями, затрагивающими интересы двух и более стран. Ввиду масштабов, тяжести и последствий указанных преступлений возникает настоятельная необходимость в совместных действиях государств-членов ЕС. В соответствии с положениями Решения Совета ЕC к 
компетентным органам относятся правоохранительные органы государств ЕC, к ведению которых относится предотвращение преступности и борьба с ней.

Практика показала, что совместное расследование преступлений трансграничного характера представителями правоохранительных органов стран имеет несомненные преимущества.

Правовую основу сотрудничества государств по совместному расследованию трансграничных преступлений составляют такие международно-правовые документы, как Конвенция ООН против транснациональной организованной преступности (от 15 ноября 2000 г.), Европейская конвенция о взаимной правовой помощи по уголовным делам (от 23 августа 2005 г.).

В той мере, в какой Европейская конвенция о взаимной правовой помощи по уголовным делам является рамочным юридическим актом регионального характера, она в полной мере вписывается в универсальную систему по противодействию международной преступности, которая была создана на основе универсальной Конвенции ООН против транснациональной организованной преступности. Каждый их обозначенных юридических актов в рамках их регулятивного воздействия содействует созданию общемировой системы противодействия международной преступности. В этом смысле выработка региональных конвенционных актов о взаимной правовой помощи предметно подтверждает решимость мирового сообщества осуществлять деятельное сотрудничество в деле поддержания международной законности и правопорядка (раздел 1 «енности и принципы» - Декларация тысячелетия 2000 г.; раздел
1 «Ценности и принципы»- Итоговый документ Всемирного саммита 2005 г.).

Международное сотрудничество правоохранительных органов государств ЕС при раскрытии и расследовании преступлений трансграничного характера осуществляется в следующих формах: совместное параллельное расследование (Joint (Parallel) Investigation - далее СПР), так называемое «зеркальное» расследование; создание объединенных следственных бригад JIT (Joint Investigation Team - далее ОСБ).

Вместе с тем, в соответствии с Конвенцией ООН против транснациональной организованной преступности от 15 ноября 2000 г. (ст. 19), а также Конвенцией $\mathrm{OOH} \mathrm{против} \mathrm{коррупции} \mathrm{от}$ 31 октября 2003 г. (ст. 49) используется еще одна форма сотрудничества - международный специализированный объединенный орган расследования (Joint Investigative Body - далее ООР).

Концептуально, оба международных конвенционных акта в рамках их предметного регулятивного воздействия постановочно работают в направлении создания универсальной системы информационной безопасности, где в должной степени юридического участия государств-членов мирового сообщества обеспечивается и поддерживается уже индивидуальная (каждая у конкретного государства) система информационной безопасности. В той мере, в какой юридическая безопасность (совокупность субъективных прав и законных интересов) носит целостный характер и не приемлет каких-либо изъятий, так и информационная безопасность (в ее качестве части единого целого) предметно исключает всякого рода изъятия и исключения из сферы своего регули- 
рования. Международная нормативная система представляет по своему юридическому существу целостную систему и в этом случае Международный суд как орган правосудия по факту переданному ему дела сторонами (ст. 36 Статута Международного суда) не может отказаться вынести решение за отсутствием или неясностью подлежащей применению нормы права $[6,10]$.

Совместное расследование в форме ОСБ по сравнению с параллельным (зеркальным) расследованием обладает преимуществом более быстрого и прямого информационного обмена, что, несомненно, важно в условиях определенного «соревнования» криминальных структур и органов правопорядка в технических и информационных возможностях. ОСБ призвана в системе би - и мультилатеральной кооперации привнести в работу европейских служб уголовного преследования большую гибкость, что характерно для организованной преступной сети.

В международном праве отсутствует определение ОСБ. Однако принимая во внимание имеющиеся в специальной литературе и в правовых соглашениях ЕС определения, можно констатировать, что объединенная следственная бригада - это образованная путем билатеральных или мультилатеральных соглашений межгосударственная оперативно-следственная группа для проведения совместного уголовного расследования в одном или более государстве ЕС на определенный установленный Сторонами срок.

ОСБ действует на территории Сторон, заключивших Соглашение о ее создании, в соответствии с общими условиями, касающимися состава персонального бригады.
Руководитель бригады - представитель компетентного органа Стороны, участвующей в расследовании уголовного преступления, под юрисдикцию которой подпадает ОСБ. Руководителями бригады в зависимости от особенностей национальных законодательств участвующих Сторон, являются государственные обвинители, судьи, старшие чиновники полиции или таможенной службы (ст. 20 (3) Второго дополнительного Протокола к Европейской конвенции о взаимной правовой помощи по уголовным делам).

Персональный состав ОСБ также включает членов бригады (members), откомандированных, или так называемых вторичных членов бригады (seconded members) и иных участников (other participants) - представителей, не участвующих в Соглашении Сторон, или сотрудников международных организаций.

К членам бригады относятся сотрудники правоохранительных органов, являющиеся гражданами той Стороны, под юрисдикцией которой работает ОСБ.

Откомандированные члены бригады (вторичные) - представители правоохранительных органов другой Стороны, которые в соответствии с Соглашением работают на территории иностранного государства в составе ОСБ.

Одной из наиболее важных новаций, предусмотренной параграфом 7 Второго дополнительного Протокола, является то, что если в ходе расследования возникает необходимость в получении правовой помощи от стороны-участницы ОСБ, то откомандированные члены бригады наделяются правом обращаться к своим национальным компетентным органам по запросу ОСБ в таком же порядке, как это предусмотрено в рамках национального 
законодательства указанной стороны. Государство, где работает ОСБ, не должно направлять отдельный запрос об оказании правовой помощи (letter rogatory) другой стороне.

Что касается необходимости прямого обмена информацией между членами ОСБ, то такой порядок предусмотрен как национальными законодательствами государств - членов ЕС, так и параграфами 9 и 10 Второго дополнительного Протокола. Эти положения дают несомненные преимущества для следователей. Члены бригады могут в соответствии с национальным законодательством страны, гражданами которой они являются, получать необходимые для уголовного расследования сведения и материалы, которые доступны в их государстве.

Информация, полученная в соответствии с законодательством участвующих сторон в ходе совместного расследования трансграничных преступлений членами или вторичными членами бригады, и которая иначе не могла стать доступной компетентным органам уголовного преследования, может быть использована в пределах, установленных положениями Соглашения между сторонами по созданию ОСБ.

Еще в первой половине прошлого столетия американский ученый Д. Митрани в работе «Система поддержания правопорядка» (a working peace system) отмечал, что если государства не способны выполнять какие-либо функции, то последние передаются специализированным международным организациям. В результате их создания смягчаются конфликтные ситуации между государствами, и, как следствие укрепляется международное сотрудничество [2].
Статья 20 Второго дополнительного Протокола к Европейской конвенции о взаимной правовой помощи предусматривает возможное присутствие в ОСБ иных участников - представителей, не участвующих в Соглашении о ОСБ сторон, или сотрудников международных организаций (Интерпол, Европол и др.).

Права, которыми наделены в соответствии с этой статьей члены бригады (например, присутствовать при проведении следственных мероприятий), не распространяются на иных участников ОСБ, если только Соглашением не предусмотрен иной порядок. Эти участники осуществляют, в основном, вспомогательные и консультативные функции и не обладают полномочиями, которыми наделены члены и вспомогательные члены бригады, а также не могут использовать полученную в ходе расследования информацию (ст. 20 (10) Второго дополнительного Протокола к Европейской конвенции о взаимной правовой помощи), если только иное не предусмотрено в Соглашении участвующих сторон.

10 сентября 2013 г. в г. Астане Совет министров внутренних дел государств - участников СНГ утвердил Концепцию развития сотрудничества министерств внутренних дел (полиции) государств участников СНГ на период до 2020 г. В соответствии с п. 5 гл. 2 Концепции к основным формам сотрудничества министерств внутренних дел государств - участников СНГ относится, в частности, создание совместных следственно-оперативных групп для раскрытия и расследования преступлений. В этом отношении интерес представляет история и опыт организации и деятельности подобных межгосударственных учреждений в Европе. 
На сайтах Евроюста и Европола широко отражена деятельность объединенных следственных бригад. Создание этих интернет-страниц преследовало цель представить информацию, в частности, о сети национальных экспертов по совместным следственным группам. Сеть была создана в 2005 г., как прямое продолжение Гаагской программы от 30 ноября 2007 г.

Евроюст и Европол считают, что вебсайт объединенных следственных бригад станет инструментом «развития», который будет способствовать расширению осведомленности о сети национальных экспертов по объединенным следственным бригадам как передового инструмента полиции разных стран и судебного сотрудничества [21].

Европол совместно с Евроюстом также подготовили справочник по законодательству государств ЕС об объединенных следственных бригадах и руководство о юридических основах и требованиях по созданию таких групп для практических работников (Eurojust and Europol 2008. Joint Investigation Team Manual). Согласно положениям данного руководства Европол и Евроюст вправе совместно требовать от государства члена ЕС создания объединенной следственной бригады. Государства-члены ЕC рассматривают запросы Европола о возбуждении, проведении или координации расследований по уголовным делам и сообщают о принятом решении. Перед обращением с запросом о возбуждении уголовного расследования Европол информирует об этом Евроюст.

Государства-члены ЕС имеет свои национальные отделы Европола, которые являются связующими звеньями между Европолом и национальными правоох- ранительными органами. Каждый национальный отдел откомандировывает в Европол, как минимум, одного офицера связи, на которого возлагается ответственность за представление интересов страны, согласно национальному законодательству государства-участника.

Офицеры связи Европола напрямую взаимодействуют с любыми членами объединенной следственной бригады и в рамках консультативной помощи предоставляют необходимую информацию из баз данных и аналитических рабочих файлов Европола.

Европол в параметрах своей международно-правовой включенности в общую систему информационной безопасности осуществляет деятельное содействие правоохранительным органам государств-членов ЕС при расследовании трансграничных преступлений. По экспертно-криминалистическим базам данных Европола ежегодно идентифицируется в среднем около 700 объектов, сотрудниками подготавливается более 900 сравнительных отчетов, предоставляется порядка 350 аналитических материалов, проводится около 340 операций. Объективные показатели международно-правовой значимости включенности Европола в общую систему информационной безопасности обозначены предметной готовностью самой организации осуществлять последовательную политику по пресечению международной преступности.

Европол использует современные информационные и коммуникационные технологии, такие как мультисервисная защищенная сеть передачи и приема данных, предоставляющие быстрые и надежные возможности для накопления криминалистической информации, ее 
визуализации и обеспечения поиска «по ключевым данным».

Поскольку сбор, анализ и распространение информации влечет за собой обмен большим количеством персональных данных, то при исполнении служебных обязанностей к сотрудникам Европола предъявляются высокие требования по защите и сохранности информации. Контроль осуществляет Объединенная наблюдательная комиссия. Так, в течение 1999 - 2000 гг. были созданы шифровальные телекоммуникационные связи с правоохранительными органами стран $\mathrm{EC}$, защищенные сети голосовой связи (secure voice network) и виртуальные частные сети (virtual private network). В 1999 г. Европол задействовал Систему по обмену информацией (Info-Ex) для обеспечения защищенного обмена криминалистической информацией между правоохранительными органами государств-членов ЕС без обязательного своего участия.

Все сервисы и базы данных Европола доступны для правоохранительных органов стран-членов ЕС круглосуточно. При необходимости оказания помощи странам-членам ЕС Европол командирует специалистов различных областей знаний, обеспечивая при этом связь с сервисами посредством мобильных пунктов оперативной связи (mobile office).

Чтобы поддерживать рост предоставляемых странам-членам ЕС, странам - не членам ЕС и третьим Сторонам услуг оперативного и стратегического характера, Европол постоянно развивает новейшие технологии, поддерживает надежность, эффективность и защищенность каналов передачи данных.

Основой инфраструктуры обмена информацией является оперативная сеть
Европола (Europol Operations Network). Она соединяет правоохранительные агентства всех стран-членов ЕС, возрастающее число правоохранительных структур стран - не членов ЕС и третьих Сторон, с которыми у Европола заключены договоры о сотрудничестве. Поэтому, в первую очередь, задача Европола состоит в обеспечение защищенности инфраструктуры сети, поскольку современная информационная безопасность базируется на возрастающем доверии среди стран, которые обмениваются информацией и сведениями конфиденциального характера с Европолом или через Европол.

Система безопасного обмена информацией сетевых приложений (Secure Information Exchange Network Application (SIENA) - далее CИЕНА) - современный инструментарий, призванный обеспечить быструю, защищенную и удобную для пользователей передачу данных, обмен оперативной и стратегической криминалистической информацией, а также оперативно-розыскными и разведывательными сведениями между Европолом, странами-членами ЕС и третьими Сторонами, имеющими договоры о сотрудничестве с Европолом. СИЕНА функционально совместима с другими системами Европола, системами сотрудничающих с Европолом государств и организаций.

Информационную систему Европола (Europol Information System) составляют базы данных криминалистической значимой информации и оперативно-аналитические учеты, содержащие сведения о преступлениях, лицах, причастных к их совершению и иную информацию (например, базы данных, содержащие персональную информацию, европейская транспортная база данных, телефонные 
базы данных, база данных огнестрельного и холодного оружия и т.п.), и которые призваны помогать странам-членам $\mathrm{EC}$, Европолу и другим компетентным органам вести борьбу с организованной преступностью, террористическими сетями и другими тяжкими и особо тяжкими преступлениями.

В информационной системе Европола содержится персональная информация, необходимая для выполнения возложенных на Европол задач по борьбе с организованной преступностью трансграничного характера. Персональные данные включают в себя следующие сведения: фамилия (девичья фамилия), имя и псевдоним, заимствованная фамилия; дата и место рождения; гражданство; пол; профессия и место нахождения соответствующего лица; номер документа о социальном обеспечении; водительское удостоверение, удостоверение личности и данные паспорта, а также при необходимости, другие сведения, позволяющие идентифицировать личность, такие как: физические приметы, дактилоскопическая и геномная информация. В информационной системе Европола также накапливаются сведения о преступлениях (дата, место, особенности и т.д.), о службах, рассматривающих уголовные дела, номера дел, судимости и иная информация, относящаяся к компетенции Европола.

Правом на внесение сведений в информационную систему Европола наделены его национальные отделы, офицеры связи и иные уполномоченные лица Европола. Базы данных Европола пополняются также за счет достоверных данных, полученных от третьих Сторон.

Абсолютное большинство информации вводится в информационные базы посредством автоматизированной системы загрузки данных. В последние годы процесс сбора криминалистической информации странами-членами ЕС изменился, и главный акцент теперь перенесен на передачу данных в различные правоохранительные органы, что требует совместимости информационных баз данных. Другой позитивной тенденцией можно считать заинтересованность национальных правоохранительных органов стран-членов ЕС в пополнении информационной системы Европола и совместном использовании ее ресурсов при раскрытии и расследовании преступлений. Такое развитие значительно улучшает качество информационной системы Европола и делает ее более эффективной и полезной для большинства правоохранительных органов европейских государств.

В качестве стратегии в этой области Совет ЕС принял решение об увеличении и более эффективном использовании возможностей информационной системы Европола в борьбе с трансграничной преступностью. Соответствующий документ устанавливает приоритетные направления деятельности для стран-членов ЕС и Европола, среди которых: расширение возможности доступа к информационной системе Европола для всех уполномоченных подразделений правоохранительных органов; установление механизма для систематического обеспечения правоохранительных органов необходимой криминалистической и иной информацией, выполнение поиска по нескольким параметрам (автоматическая функция дает возможность осуществлять до 400 индивидуальных поисков одновременно); более широкое использование возможно- 
стей информационной системы Европола при проведении расследований.

Чтобы обеспечить действенное и скоординированное противодействие преступности Европол призван быть в равной степени маневренной и инновационной организацией, обеспечивающей развитие передовых средств и методов раскрытия и расследования преступлений и оснащенной оборудованием и криминалистической техникой, в полной мере соответствующей современным требованиям.

Информационная система Европола, которая позволяет обмениваться «высоко уязвимой информацией», имеет секретную робастную систему защиты (устойчивую к внешним воздействиям). Безопасность гарантируется, помимо иных средств защиты, загрузочными кодами. Данная функция обеспечивает максимальную защиту и определяет лиц, кто может быть допущен к информации и что должно быть для этого сделано.

Европол в целях усиления своей позиции как ведущего органа в сфере специальных знаний, а также для обмена опытом и связями между различными объединениями экспертов и специалистов, развивает специальные базы (платформы) для экспертов (Europol Platform for Expert - далее ЕРЕ), которые представляют собой защищенную операционную систему. $\mathrm{C}$ ее помощью специалисты различных правоохранительных структур имеют возможность в рамках соответствующих объединений обмениваться знаниями, передовым опытом и не персональной криминалистической информацией. Указанная система оказывает помощь в сотрудничестве экспертов и специалистов различных стран благодаря совместной работе в режиме on-line.
В последние годы число пользователей ЕРЕ возросло на 2000 участников, а для пользователей открыта специальная тематическая информация.

Европол в рамках своей деятельности по поддержанию международной законности и правопорядка осуществляет содействие следственным органам стран-членов ЕС в режиме удаленного доступа по следующим видам преступлений: подделка платежных карт; преступления в интернете (сетевая преступность); фальшивомонетничество (подделка евро), производство контрафактных товаров, подделка документов; незаконное производство наркотиков, их хранение и места складирования.

Европол как ведущая организация Евросоюза по борьбе с поддельными евро является международным контактным пунктом по борьбе с фальшивомонетничеством. Выполняя возложенные на него обязательства, Европол предоставляет правоохранительным органам экспертную помощь в проведении экспертиз и исследований материалов денежных купюр, а также технических средств, с помощью которых изготавливаются фальшивые евро. В дополнении, Европол организовывает учебные курсы по вопросам защищенности евро от подделок.

На территории ЕС незаконно производится большое количество синтетических наркотиков, особенно амфетомина и экстази. Ежегодно от 60 до 90 мест серийного производства наркотиков обнаруживается, арестовывается и ликвидируется. Часто во время следствия правоохранительные органы также находят места складирования химических прекурсоров, которые используются при производстве наркотиков и представляют 
потенциальную опасность. Специалисты Европола оказывают помощь в подготовке секретных операций по ликвидации незаконных производств наркотиков и сбору доказательств. Они выполняют технические исследования индивидуально изготовленного или промышленного оборудования, захваченного в результате ликвидации подпольных цехов и складов.

Лаборатория Европола по системному исследованию нелегальных производств наркотиков (The Europol Illicit Laboratory Comparison System - EILCS) проводит детальные исследования фотографической или технической информации по производству синтетических наркотиков, местам их складирования и захоронения. Это дает возможность идентифицировать изъятые объекты, такие как оборудование, материалы и химические реагенты.

Постановочно, информационная система Европола по синтетическим наркотикам (The Europol Synthetic Drug System - ESDS) включает в себя информацию о методиках проведения операций по захвату и изъятию незаконной продукции. Существует также база данных, содержащая информацию о современных способах сокрытия транспортировки кокаина, которые применяют преступные группировки (The Europol Specific Means of Concealment - ESMC).

Европол предоставляет правоохранительным органам стран-членов ЕС в режиме удаленного доступа оборудование для проведения криминалистических экспертиз и исследований, как, например, универсальное устройство для извлечения информации (Universal Forensic Extraction Device (UFED)), являющее собой автономный переносной прибор, способный извлекать информацию из 95\% мобильных телефонов и персональных компьютеров. Полученная информация затем может быть направлена в криминалистическую лабораторию для проведения контрольной проверки.

Принимая во внимание вышеизложенное, можно говорить о существенном вкладе Европола в активизацию межгосударственного сотрудничества европейских государств в борьбе с трансграничной организованной преступностью, в частности в создании благоприятной среды для своевременного и эффективного обмена криминалистической и иной информацией при раскрытии и расследовании преступлений.

Международно-правовое позиционирование института информационной безопасности в контексте взаимодействия государств-членов Европейского Союза по противодействию международной преступности предметно ориентировано на создание и поддержание универсальной системы информационной безопасности в интересах всего мирового сообщества.

Российская Федерация в своем статусном положении Великой державы, постоянного члена Совета Безопасности ООН, предметно заявившего о своей приверженности верховенству права (Декларация тысячелетия 2000 г., Итоговый документ Всемирного саммита 2005 г.), занимает важное место в универсальной системе информационной безопасности. В рамках своего последовательного курса на поддержание международной законности и правопорядка Российской государство осуществляет деятельное взаимодействие с другими государствами членами мирового сообщества (в частности, с государствами-членами Европейского Союза) по обеспечению целостности универсальной 
системы информационной безопасности с предметной целью содействия общим усилиям мирового сообщества по пресечению международной преступности. Международно-правовая значимость включенности Российской Федерации в универсальную систему информационной безопасности по линии борьбы мирового сообщества с международной преступностью обозначена конкретной готовностью Российского государства внести свой собственный (соизмеримый с его местом в современном миропорядке) вклад в дело обеспечения международной законности и правопорядка.

Позитив вклада Российской Федерации в международную нормативную систе- му установлен по факту предметного содействия добросовестному выполнению всеми государствами-членами ООН своих международных обязательств. Тем самым качественные показатели права конкретным образом проявляют себя в параметрах действующей универсальной международной безопасности.

Последовательный внешнеполитический курс Российского государства в порядке заявленной приверженности верховенству права оказывает качественно позитивное воздействие на всю современную международную нормативную систему. Справедливый миропорядок тем самым обозначает себя в формате реально действующей системы международных отношений.

\section{Библиография:}

1. Волеводз А. Некоторые организационные аспекты сотрудничества в борьбе с преступностью в Европейском Союзе / Уголовное право: Научно-практический журнал. 2009. № 4. С. 110.

2. Воробьев И.А. Международное сотрудничество в борьбе с транснациональной организованной преступностью. М., 2004. С. 24.

3. Дмитриева Г.К. Принцип добросовестности в современном международном праве / Правоведение. 1979. № 6. С. 85-86.

4. Дмитриева Г.К. Становление принципа недопустимости злоупотребления правом / Советский ежегодник международного права. 1987. М, 1988. С. 114 - 117.

5. Иванов И.С. Верховенство права в международных отношениях / Международная жизнь. 2000. № 12. С. $62-67$.

6. Каламкарян P.А. Господство права Rule of Law в международных отношениях. М., 2004. C. 256-269.

7. Каламкарян Р.А. Принцип добросовестности в современном международном праве. М., 1990.

8. Cheng B. General Principles of Law as Applied by International Courts and Tribunals, London, 1953. P. 121-136;

9. Dicey A.V. Introduction to the Study of the Law of Constitution. London, 1960. P. 183-206;

10. International Law: Being the Collected Papers of H. Lauterpacht. Cambridge, 1970. Vol. I. P. 243; Vol. 2. P. 224-225.

11. Jackson S.W. The rule of law among nations / The Rule of Law. Dallas, 1961. P. 71-86.

12. Jacque J. - P. Eléments pour une theorie de l'acte juridique en droit international public. Paris, 1972. P. 171.

13. Oppenheim L. International Law / Ed. by H. Lauterpacht. London, 1958.Vol. 1 P. 345-347; Rousseau Ch. Droit International Public. Paris, 1970. Vol. 1 P. 382-383.

14. Official Journal C 193/2 of 24.06.1997.

15. O. J. of European Union 2007/C 306/01. URL: europa.eu/reform-treaty

16. O.J. of the European Union № L121. 15 May 2009. Brussels, 2009. P. 37-66

17. OL L 210, 200886

18. Paul V. The Abuse of Rights and Bona Fides in International Law / Österreichishe Zeitschrift für öffentliches Recht und Völkerrect. 1977. Bd. 28 N. 1/2. S. 125, 127, 128/ 129. 
19. Renouf A. The rule of law in international affairs / Australian Foreign Affairs Record. 1975. July. P. 395-405.

20. Ronsseau Ch. Droit International Public. Paris, 1970. Vol. 1 P. 382-383.

21. Ten years of Europol 1999 - 2009/ European police office, 2009. P. 51.

22. Zoller E. La bonne foi en droit international public. Paris, 1977. P. 350

23. Дамирчиев Эмин Исахан оглы Основные направления практической деятельности Европейской полицейской организации (Европол) в сфере борьбы с преступностью. // Полицейская деятельность. $-2011 .-2 .-$ С. $49-59$.

24. Владимирова Т.В. Об обеспечении информационной безопасности в условиях киберпространства // Вопросы безопасности. - 2014. - 3. - C. 132 - 157. DOI: 10.7256/2409-7543.2014.3.12525. URL: http:// www.e-notabene.ru/nb/article_12525.html

\section{References (transliterated):}

1. Volevodz A. Nekotorye organizatsionnye aspekty sotrudnichestva v bor'be s prestupnost'yu v Evropeiskom Soyuze / Ugolovnoe pravo: Nauchno-prakticheskii zhurnal. 2009. № 4. S. 110.

2. Vorob'ev I.A. Mezhdunarodnoe sotrudnichestvo $\mathrm{v}$ bor'be $\mathrm{s}$ transnatsional'noi organizovannoi prestupnost'yu. M., 2004. S. 24.

3. Dmitrieva G.K. Printsip dobrosovestnosti v sovremennom mezhdunarodnom prave / Pravovedenie. 1979. № 6. S. 85-86.

4. Dmitrieva G.K. Stanovlenie printsipa nedopustimosti zloupotrebleniya pravom / Sovetskii ezhegodnik mezhdunarodnogo prava. 1987. M, 1988. S. 114 - 117.

5. Ivanov I.S. Verkhovenstvo prava v mezhdunarodnykh otnosheniyakh / Mezhdunarodnaya zhizn'. 2000. № 12. S. 62-67.

6. Kalamkaryan R.A. Gospodstvo prava Rule of Law v mezhdunarodnykh otnosheniyakh. M., 2004. S. 256-269.

7. Kalamkaryan R.A. Printsip dobrosovestnosti v sovremennom mezhdunarodnom prave. M., 1990.

8. Cheng B. General Principles of Law as Applied by International Courts and Tribunals, London, 1953. P. 121-136;

9. Dicey A.V. Introduction to the Study of the Law of Constitution. London, 1960. P. 183-206;

10. Jackson S.W. The rule of law among nations / The Rule of Law. Dallas, 1961. P. 71-86.

11. Jacque J. - P. Eléments pour une theorie de l'acte juridique en droit international public. Paris, 1972. P. 171.

12. Oppenheim L. International Law / Ed. by H. Lauterpacht. London, 1958.Vol. 1 P. 345-347; Rousseau Ch. Droit International Public. Paris, 1970. Vol. 1 P. 382-383.

13. Paul V. The Abuse of Rights and Bona Fides in International Law / Österreichishe Zeitschrift für öffentliches Recht und Völkerrect. 1977. Bd. 28 N. 1/2. S. 125, 127, 128/ 129.

14. Renouf A. The rule of law in international affairs / Australian Foreign Affairs Record. 1975. July. P. 395-405.

15. Ronsseau Ch. Droit International Public. Paris, 1970. Vol. 1 P. 382-383.

16. Zoller E. La bonne foi en droit international public. Paris, 1977. P. 350

17. Damirchiev Emin Isakhan ogly Osnovnye napravleniya prakticheskoi deyatel'nosti Evropeiskoi politseiskoi organizatsii (Evropol) v sfere bor'by s prestupnost'yu. // Politseiskaya deyatel'nost'. - 2011. - 2. - C. $49-59$.

18. Vladimirova T.V. Ob obespechenii informatsionnoi bezopasnosti v usloviyakh kiberprostranstva // Voprosy bezopasnosti. - 2014. - 3. - C. 132 - 157. DOI: 10.7256/2409-7543.2014.3.12525. URL: http://www.e-notabene.ru/nb/article_12525.html 